\title{
Phytoncides in the prevention and therapy of blackhead disease and their effect on the turkey immune system
}

\author{
Bartłomiej Tykałowski ${ }^{\varpi}$, Marcin Śmiałek, Joanna Kowalczyk, \\ Daria Dziewulska, Tomasz Stenzel, Andrzej Koncicki \\ Department of Poultry Diseases, Faculty of Veterinary Medicine, \\ University of Warmia and Mazury, 10-719 Olsztyn, Poland \\ bartlomiej.tykalowski@uwm.edu.pl
}

Received: July 23, $2020 \quad$ Accepted: January 20, 2021

\begin{abstract}
Introduction: Turkey histomonosis poses a serious threat to poultry production due to the ban on the use of effective drugs. The aim of the study was to evaluate the influence of a phytoncidal feed supplement on the course of histomonosis. The preparation was also analysed for immunomodulatory properties. Material and Methods: Clinical observations and production monitoring were conducted in a flock of turkeys with histomonosis from their $11^{\text {th }}$ to $56^{\text {th }}$ weeks of life which were treated with the adiCox ${ }^{\mathrm{SOL} P F}$ soluble supplement in a dose of $2.5 \mathrm{~mL} / \mathrm{L}$ water. Later the preparation was used in a preventive dose $(1 \mathrm{~mL} / \mathrm{L})$. The influence on

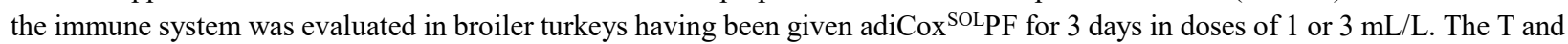
B lymphocyte percentages in turkey blood and spleen tissue were analysed with flow cytometry. ELISA was implemented to evaluate antibody titres after Ornithobacterium rhinotracheale vaccination, and biochemical analyses were performed to evaluate the supplement's safety. Results: AdiCox ${ }^{\text {SOLPF }}$ was found effective in therapy and prevention of histomonosis. Additionally,

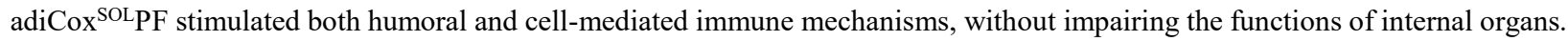
The treated turkeys also yielded better production results (eggs/hen, fertility, and hatchability). Conclusion: AdiCox $^{\text {SOL } P F}$ possesses immunomodulatory properties and it can be used successfully in the prevention and therapy of histomonosis in turkeys.
\end{abstract}

Keywords: turkey, histomonosis, phytoncides, prevention, therapy.

\section{Introduction}

Of the many avian parasites, the Histomonas meleagridis protozoan flagellate and causative agent of histomonosis, or blackhead disease, is a particularly dangerous one. Histomonosis is most common among 2-16-week-old turkeys; however, it is also diagnosed in older birds (26). Even though chickens and other bird species are considered less susceptible to infection and despite the milder course of the disease in them, many clinical cases of histomonosis in poultry in different production systems have recently been described in gallines $(3,8,27,28,33)$.

Turkey infection with $H$. meleagridis occurs per os with Heterakis gallinarum eggs. Infection with these flagellates may also spread without the participation of these nematodes, and the penetration route of the protozoa is then through the cloaca $(14,18,19)$. The pathogenesis of histomonosis starts with the colonisation of the caecum by the parasite, leading to severe inflammation and necrosis. Following the destruction of intestinal tissue, the parasite may infiltrate blood vessels and reach the liver via the portal veins. As a consequence, areas of inflammation and destruction can be created in the liver. In the final stage, the disease may become systemic when the parasite spreads to other organs of the host (13). The incidence and mortality of turkeys infected with this protozoan can reach $100 \%$. Histomonosis manifests with clinical signs such as reduced appetite, sulphur-yellow diarrhoea, dehydration, and emaciation $(19,20,26)$.

Cases of histomonosis in poultry flocks are frequent in many countries of the European Union and across the world. This re-emerging endemic disease poses a serious threat to the breeding of birds, mainly turkeys, and confronts the industry with major clinical, epidemiological, and economic problems $(9,17,25)$. This unfavourable situation is caused by a ban on the 
prophylactic and therapeutic use of effective chemotherapeutics in poultry, notable preparations affected by the ban being those containing derivatives of nitroimidazoles (metronidazole, ronidazole, and dimetridazole) (6) and nitrofurans (nifursol) (7). International guidelines for food safety, including those on veterinary drug residues in food, are outlined in the Codex Alimentarius of the Food and Agriculture Organization of the United Nations and the World Health Organization, and regarding histomonostats, they strongly recommend not to use nitroimidazoles such as metronidazole or dimetridazole in foodproducing birds (5). The ban on administering these substances to domestic birds addresses the risk of their residues being present in foodstuffs and posing a threat to consumer health (2).

This situation and the fact that biosecurity measures do not always prevent $H$. meleagridis introduction into a flock, infection (4), or ultimate disease outbreak, have forced a new approach to the problem of histomonosis prevention and treatment. That is why recent research focuses on various areas of disease control from the use of phytocompounds $(1,12,31)$ to administration of vaccines $(25,29)$. The presented study aims to assess the therapeutic and preventive efficacy of phytoncides contained in adiCox ${ }^{\text {SOLPF }}$ (AdiFeed, Warsaw, Poland), a feed supplement for poultry, in a clinical case of histomonosis in a parent turkey flock, as well as to determine their effect on selected parameters of bird cell-mediated and humoral immunity.

\section{Material and Methods}

Dietary supplement. The adiCox ${ }^{\mathrm{SOL} P F}$ dietary supplement for turkeys contains $52.0 \%$ herbal extracts including sweet flag (Acorus calamus L.), saponaria (Saponaria officinalis L.), mustard (Sinapis alba L.), and pepper (Piper nigrum L.); 9.2\% flavouring additives including thymol; and preservatives including acetic acid $(4.6 \%)$, calcium lactate $(0.6 \%)$, and sodium diacetate $(0.2 \%)$.

Case presentation, clinical history, and treatment. The turkey farm where the studied birds were reared operated on the all-in/all-out system. There were two turkey houses ( $\mathrm{J}-1$ and $\mathrm{J}-2$ ) on the farm and 9,339 one-day-old turkey poults were housed in them in total. In the J-2 turkey house, a clinical form of histomonosis occurred when the turkeys were aged 11 weeks in a flock designated as breeders. Within the next seven days, 48 turkey hens out of 3,870 placed in $\mathrm{J}-2$ were found dead. In the same poultry house, 1,019 turkey toms were reared in a sector separated by a solid wall. The turkeys were administered adiCox ${ }^{\text {SOLPF }}$ in a dose of $2.5 \mathrm{~mL} / \mathrm{L}$ water in 3 seven-day cycles, with a two-day break after each.

In $\mathrm{J}-1$, the 4,450 turkey hens kept there were administered the preparation for seven days in a dose of $2.5 \mathrm{~mL} / \mathrm{L}$ water and then in two subsequent cycles in a dose of $1 \mathrm{~mL} / \mathrm{L}$. Next, the depressed and emaciated turkey hens from J-2 were culled. Afterwards, the floor in J-2 was bedded with a thick straw layer, and all birds were dewormed by two-day administration of Levamol 10\% (Vetoquinol Biowet Sp. z o.o., Gorzów Wielkopolski, Poland) in a dose of $0.3 \mathrm{~mL} / \mathrm{kg}$ body weight in drinking water. For two consecutive days, the gastrointestinal tract of turkeys was colonised by physiological bacterial flora (Protexin, Probiotics Int. Ltd., Lopen Head, UK) and then the birds were administered multivitamin preparations for another two days. After these treatments, adiCox ${ }^{\mathrm{SOL}} \mathrm{PF}$ was re-administered for seven days in a dose of $2.5 \mathrm{~mL} / \mathrm{L}$ water in $\mathrm{J}-2$, and $1 \mathrm{~mL} / \mathrm{L}$ water in $\mathrm{J}-1$.

Until the end of the growing-out stage, i.e., until week 28 of life, the birds received adiCox ${ }^{\text {SOL }} \mathrm{PF}$ in a dose of $1 \mathrm{~mL} / \mathrm{L}$ water in seven-day cycles with a three-day break between them. In week 29 of life, the birds were transferred to a laying farm. The turkey hens that had been reared in $\mathrm{J}-2$ were placed in a separate poultry house $(\mathrm{P}-1)$ and were administered adiCox ${ }^{\mathrm{SOL}} \mathrm{PF}$ in a dose of $1 \mathrm{~mL} / \mathrm{L}$ water in seven-day cycles with a sevenday break between them until the end of laying production. In turn, the hens reared in $\mathrm{J}-1$ were transferred to poultry houses P-2 and P-3. Along with toms which were also transferred to poultry houses P-2 and P-3, these hens received the supplement in a dose of $1 \mathrm{~mL} / \mathrm{L}$ water in three-day cycles with an eleven-day break between them until the end of the laying period.

Eggs/hen, fertility, hatchability, and mortality and culling rates were monitored in all poultry houses.

Necropsy, parasitological and microbiological examination. During anatomopathological examination, tissue sections (liver, spleen, heart, ileum, and caecum) were collected for parasitological and microbiological analyses and detection of $H$. meleagridis genetic material. Caecal contents were washed with water and viewed under a stereoscopic microscope for the presence of $H$. gallinarum. Additionally, faeces samples from sick birds were tested for the presence of this nematode by the flotation technique. Three grams of faeces from each turkey were mixed with $15 \mathrm{~mL}$ of Fecasol (Vetoquinol Biowet) solution and strained through a $0.5 \mathrm{~mm}$ mesh sieve. The suspension was transferred to a $15 \mathrm{~mL}$ tube and centrifuged at $1,500 \times \mathrm{g}$ for $5 \mathrm{~min}$. The test sample was removed from each tube by touching the surface of the supernatant with a microscopic slide and then it was examined under $100 \times$ magnification.

Microbiological examination was performed on samples from the liver, spleen, heart, and ileum, which were cultured in standard and selective media (Columbia agar with 5\% sheep blood and MacConkey agar, Oxoid Deutschland GmbH, Wesel, Germany).

DNA isolation and PCR amplification. Liver and caecum samples $(0.2 \mathrm{~g}$ each) were individually cut into fragments $1-2 \mathrm{~mm}$ in diameter. The fragments were placed in an Eppendorf tube, $700 \mu \mathrm{L}$ of sterile PBS was added, and the samples were homogenised using a TissueLyser II automatic device (Qiagen, Hilden, 
Germany). The resulting homogenate was centrifuged at $8,000 \times \mathrm{g}$ for $30 \mathrm{~s}$. Next, a $200 \mu \mathrm{L}$ cell pellet was collected for DNA isolation, which was performed using a DNeasy Blood \& Tissue Kit (Qiagen), following the manufacturer's instructions. The concentration and quality of the isolated DNA were evaluated with a NanoDrop 2000 spectrophotometer (Thermo Fisher Scientific, Waltham, MA, USA).

The PCR method described by Grabensteiner and Hess (11) was employed to detect $H$. meleagridis genetic material in the liver and caecum samples. The eluted DNA concentration was optimised to $150 \mathrm{ng} /$ reaction and amplified with the use of a HotStarTaq Plus Master Mix Kit (Qiagen) in a Vapo Protect thermal cycler (Eppendorf, Hamburg, Germany).

The PCR amplicon size was analysed by electrophoresis in 2\% agarose gel (Prona Agarose; ABO, Gdańsk, Poland) in $1 \mathrm{X}$ concentrated TAE buffer (Fermentas, Vilnius, Lithuania) with ethidium bromide addition at $0.5 \mu \mathrm{L} / \mathrm{mL}$ (Sigma-Aldrich, St. Louis, MO, USA) using $5 \mathrm{~V} / \mathrm{cm}$ gel voltage for $60 \mathrm{~min}$. DNA Marker (A\&A Biotechnology, Gdynia, Poland) was used as a molecular size marker. The results of the electrophoretic separation were read via GelDoc XR+ visualisation (Bio-Rad, Hercules, CA, USA) and saved as digital images.

Turkeys, experimental groups and handling. Experiment I was conducted on thirty 46-day-old Hybrid Converter turkeys (Grelavi S.A., Olsztyn, Poland) randomly divided into three groups (A1-A3) of 10 birds each. Group A1 was the control, while birds from groups $\mathrm{A} 2$ and $\mathrm{A} 3$ were administered adiCox ${ }^{\text {SOLPF }}$ for three days in drinking water at a final dose of $1 \mathrm{~mL}$ or $3 \mathrm{~mL} / \mathrm{L}$, respectively.

Experiment II was conducted on sixty-nine 46-day-old Hybrid Converter broiler turkeys (Grelavi S.A., Olsztyn, Poland) randomly divided into three groups (B1-B3) of 23 birds each. The birds from group B1 were given adiCox ${ }^{\mathrm{SOL} P F}$ for three days in drinking water at a final dose of $1 \mathrm{~mL} / \mathrm{L}$. All birds from groups B1, B2, and B3 were vaccinated against Ornithobacterium rhinotracheale (ORT) at 49 days of life. After vaccination, birds from group B2 were administered adiCox ${ }^{\mathrm{SOL}} \mathrm{PF}$ for three days in drinking water at a final dose of $1 \mathrm{~mL} / \mathrm{L}$, while birds from group B3 did not receive the phytoncidal preparation at any time during the experiment.

Turkeys were housed in isolated pens in a biosafety level-3 facility. Water and feed were provided ad libitum. The experimental procedures and animal handling procedures were approved by the Local Ethics Committee for Animal Experiments in Olsztyn, Poland.

Vaccine and vaccination. In experiment II, turkeys from groups B1, B2, and B3 were vaccinated against ORT with Ornitin (ABIC Biological Laboratories Ltd., Airport City, Israel) at 49 days of life. The vaccine was administered subcutaneously following the manufacturer's instructions.

Sample collection. In experiment I, blood samples were collected from turkeys of groups A1-A3 by venipuncture of the wing into sterile tubes without anticoagulant for biochemical analyses $(n=10)$ and into sterile tubes containing EDTA K anticoagulant for flow cytometry analysis $(n=7)$. Samples were collected $10 \mathrm{~h}$ after the last adiCox ${ }^{\text {SOLPF }}$ supplement was given. Seven birds from each group were euthanised, samples of their spleens were collected, and together with blood samples these were used to isolate mononuclear cells and determine the percentages of $\mathrm{CD}^{+}, \mathrm{CD}^{+}$, and $\mathrm{CD}^{+} \mathrm{CD}^{+} \mathrm{T}$ cell subpopulations and the $\mathrm{IgM}^{+} \mathrm{B}$ cell subpopulation by flow cytometry. Humane euthanasia of the birds was performed using a professional UNO Euthanasia $\mathrm{CO}_{2}$ unit (UNO, Zevenaar, the Netherlands).

In experiment II, blood samples for serological analyses were collected from 23 birds from groups B1-B3 on the day of ORT vaccination and three weeks post vaccination.

Serological analysis. Anti-ORT IgY titres were determined using a commercial immunoenzymatic ELISA kit (IDEXX Laboratories, Westbrook, MN, USA) according to the manufacturer's recommendations. The ELISA assay was performed using an epMotion 5075 LH automated pipetting system (Eppendorf), an Elx405 washer, and an Elx800 absorbance microplate reader (BioTek, Winooski, VT, USA).

Biochemical analyses. The levels of total protein (TP) and the activities of the alanine aminotransferase (ALT), aspartate aminotransferase (AST), alkaline phosphatase (ALP), lactate dehydrogenase (LDH), and creatine kinase $(\mathrm{CK})$ enzymes were determined in blood serum samples. The tests were performed using a VetTest Chemistry Analyzer (IDEXX) according to the manufacturer's instructions.

Isolation of mononuclear cells and flow cytometry. Peripheral blood mononuclear cells (PBMCs) were isolated according to a previously described procedure (22). The isolation of mononuclear cells from the spleen and the determination of the percentages of $\mathrm{CD}^{+}$and $\mathrm{CD}^{+} \mathrm{T}$ cell and $\mathrm{IgM}^{+} \mathrm{B}$ cell subpopulations in PBMCs and spleen were carried out as described by Kubińska et al. (24).

Statistical analysis. The significance of differences in values of the measured parameters between the investigated groups was analysed with Student's $t$-test for independent variables. All calculations were made using Statistica 13.1 software (StatSoft, Tulsa, OK, USA). Differences were considered statistically significant at $\mathrm{P} \leq 0.05$.

\section{Results}

Clinical observations. Sick turkeys displayed apathy, were emaciated with their wings down, and had dull plumage and sulphur-yellow faeces adhering to the area around the cloaca. All dead turkeys were dissected, and the following pathological changes were noticed during necropsy. The livers were enlarged and ulcerated lesions with circular depressions up to $1 \mathrm{~cm}$ 
in diameter had formed on the surface, which were light yellow in the centre and raised at their peripheries. The caeca were bloated and contained caseous matter; after the removal of the contents, necrosis and ulcers of the caecal wall were seen. No adult $H$. gallinarum nematodes were found in the caecal contents, and no eggs of these parasites were found in faeces during parasitological examination with the flotation method. Microbiological analyses demonstrated numerous E. coli in the internal organs of dead birds. Histomonosis was additionally diagnosed based on the presence of the parasite's genetic material in the liver and caecum samples (Fig. 1).

During the administration of the tested preparation, no disease cases were found among toms from $\mathrm{J}-2$ or hens from $\mathrm{J}-1$. Within four weeks of the onset of the disease, 229 (5.92\%) turkey hens died and 630 (16.28\%) were euthanised, representing $22.20 \%$ of the total. Over the entire 28 -week growing-out period, the mortality and culling rate was $28.3 \%$ in $\mathrm{J}-2$ and $4.53 \%$ in $\mathrm{J}-1$.

After transfer to the production facilities, turkey hens began laying in week 32 of life. Production parameters (eggs/hen, fertility, and hatchability) and the mortality and culling rate determined over the laying production period are summarised in Table 1. On average, 112 eggs were produced by each turkey hen from $\mathrm{P}-1$, whereas in $\mathrm{P}-2$ and $\mathrm{P}-3$ the production rate was higher by 5 and 7 eggs, respectively. Irrespective of the turkey house, fertility and hatchability were at $97 \%$ and $85 \%$, respectively. In the studied period, $6.1 \%$ of birds died or were culled in P-1, whereas the mortality and culling rate in P-2 and P-3 was $2.7 \%$ and $3.4 \%$, respectively. No cases of histomonosis were recorded in any of the birds which were found dead or were euthanised.

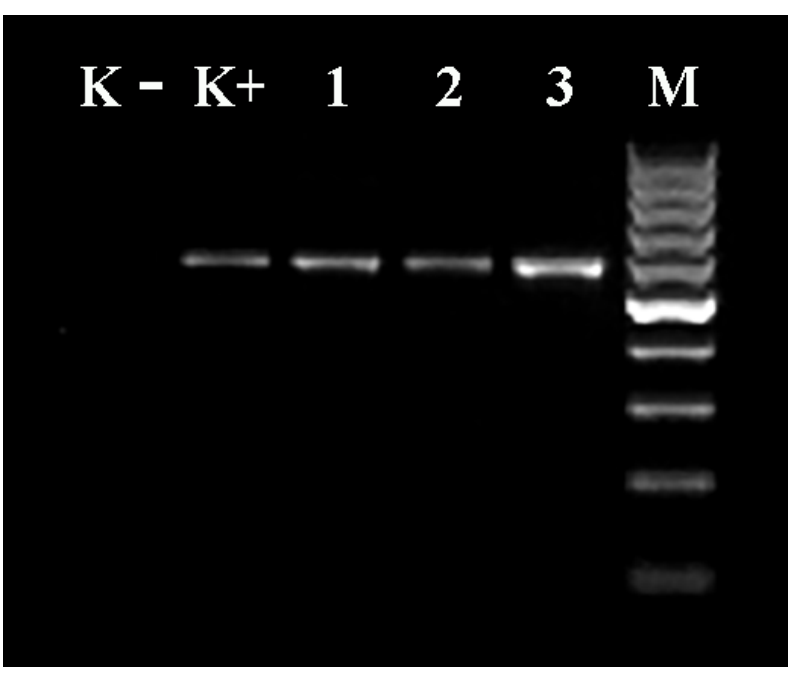

Fig. 1. Detection of $H$. meleagridis by PCR assay

$\mathrm{K}-$ - negative control; $\mathrm{K}+$ - positive control (574 bp); 1, 2 - DNA samples isolated from liver; 3 - DNA sample isolated from caecum; $\mathrm{M}$ - molecular size marker (100-1000 bp)

Experiment I. The dose of the preparation administered to turkeys had no effect on water and feed intake. The results of biochemical analyses are summarised in Table 2. All presented values fell within the ranges of standard physiological values. Graded levels of supplementation with adiCox ${ }^{\text {SOLPF }}$ had no significant effect on the analysed parameters.

Table 1. Mean values of production parameters and the mortality and culling rate in the laying production period (week 32 to week 56 of life) in a reproductive flock of turkeys treated for histomonosis diagnosed in the rearing period

\begin{tabular}{lccc}
\hline \multirow{2}{*}{ Parameter } & \multicolumn{3}{c}{ Turkey house } \\
\cline { 2 - 4 } & P-1 & P-2 & P-3 \\
\hline Eggs/hen & 112 & 117 & 119 \\
\hline Mortality and culling (\%) & 6.1 & 2.7 & 3.4 \\
\hline & & P-1, P-2, and P-3 & \\
\hline Fertility (\%) & & 97 & \\
\hline Hatchability (\%) & & 85 & \\
\hline
\end{tabular}

P-1 - the poultry house used to hold hens from J-2 where there was an outbreak of clinical histomonosis during the rearing period

$\mathrm{P}-2, \mathrm{P}-3$ - the poultry houses used to hold hens from $\mathrm{J}-1$ and toms from $\mathrm{J}-2$

Table 2. Mean value \pm SD of biochemical markers in blood serum of turkeys from experiment $\mathrm{I}(\mathrm{n}=10)$

\begin{tabular}{ccccccc}
\hline Group & ALT $(\mathrm{U} / \mathrm{L})$ & AST $(\mathrm{U} / \mathrm{L})$ & ALP $(\mathrm{U} / \mathrm{L})$ & CK $(\mathrm{U} / \mathrm{L})$ & LDH $(\mathrm{U} / \mathrm{L})$ \\
\hline A1 & $15.83 \pm 1.26$ & $261.67 \pm 14.39$ & $2056.67 \pm 110.32$ & $1287.90 \pm 260.08$ & $942.00 \pm 91.42$ & $35.45 \pm 2.26$ \\
A2 & $16.00 \pm 2.10$ & $250.50 \pm 18.97$ & $1768.83 \pm 360.05$ & $1450.92 \pm 255.59$ & $1002.83 \pm 88.23$ & $35.61 \pm 1.65$ \\
A3 & $17.33 \pm 3.39$ & $275.33 \pm 39.26$ & $2311.33 \pm 542.02$ & $1934.52 \pm 399.42$ & $1034.17 \pm 67.31$ & $35.63 \pm 4.25$ \\
\hline
\end{tabular}

A1 - control group

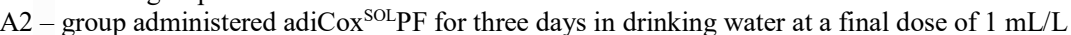

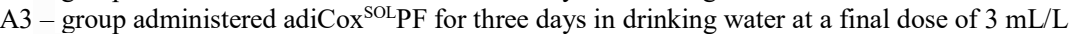

ALT - alanine aminotransferase; AST - aspartate aminotransferase; ALP - alkaline phosphatase; CK - creatine kinase; LDH - lactate

dehydrogenase; $\mathrm{TP}$ - total protein 
Table 3. Mean percentage of $\mathrm{CD}^{+}, \mathrm{CD} 8^{+}$, and $\mathrm{CD} 4^{+} \mathrm{CD} 8^{+} \mathrm{T}$ lymphocytes and $\mathrm{IgM}^{+} \mathrm{B}$ cells $\pm \mathrm{SD}$ in blood and spleen of turkeys from experiment $\mathrm{I}$ $(\mathrm{n}=7)$

\begin{tabular}{ccccccccc}
\hline \multirow{2}{*}{ Group } & \multicolumn{4}{c}{ Blood } & \multicolumn{3}{c}{ Spleen } \\
& $\mathrm{CD}^{+}$ & $\mathrm{CD}^{+}$ & $\mathrm{CD}^{+} \mathrm{CD}^{+}$ & $\mathrm{IgM}^{+}$ & $\mathrm{CD}^{+}$ & $\mathrm{CD}^{+}$ & $\mathrm{CD}^{+} \mathrm{CD}^{+}$ & $\mathrm{IgM}^{+}$ \\
\hline $\mathrm{A} 1$ & $16.95^{\mathrm{a}} \pm 2.44$ & $2.20 \pm 0.38$ & $0.57 \pm 0.08$ & $10.86 \pm 0.99$ & $34.80 \pm 6.80$ & $21.35 \pm 6.14$ & $1.32 \pm 0.36$ & $17.47^{\mathrm{a}} \pm 2.21$ \\
$\mathrm{~A} 2$ & $23.68^{\mathrm{b}} \pm 4.88$ & $2.19 \pm 0.70$ & $0.71 \pm 0.17$ & $11.55 \pm 1.15$ & $37.27 \pm 7.38$ & $25.15 \pm 10.00$ & $1.46 \pm 0.37$ & $20.85^{\mathrm{ab}} \pm 2.10$ \\
$\mathrm{~A} 3$ & $18.53^{\mathrm{ab}} \pm 6.05$ & $2.17 \pm 0.42$ & $0.57 \pm 0.11$ & $11.54 \pm 0.98$ & $33.15 \pm 3.19$ & $28.40 \pm 8.49$ & $1.55 \pm 0.54$ & $22.10^{\mathrm{b}} \pm 3.32$ \\
\hline
\end{tabular}

A1 - control group

A2 - group administered adiCox ${ }^{\mathrm{SOL}} \mathrm{PF}$ for three days in drinking water at a final dose of $1 \mathrm{~mL} / \mathrm{L}$

A 3 - group administered adiCox ${ }^{\mathrm{SOL}} \mathrm{PF}$ for three days in drinking water at a final dose of $3 \mathrm{~mL} / \mathrm{L}$

$\mathrm{a}, \mathrm{b}-$ means with different superscripts in the same column differ significantly $(t$-test, $\mathrm{P}<0.05)$

Table 4. Mean geometric titre of post-vaccination anti-ORT IgY antibodies in blood serum and $\% \mathrm{CV}$ of turkeys from experiment II $(\mathrm{n}=23)$

\begin{tabular}{ccccc}
\hline \multirow{2}{*}{ Group } & \multicolumn{2}{c}{ Day of vaccination } & \multicolumn{2}{c}{3 weeks post vaccination } \\
& ORT (titre) & ORT $(\% \mathrm{CV})$ & ORT (titre) & ORT (\%CV) \\
\hline B1 & 128 & 137 & 2,312 & 64 \\
B2 & 123 & 129 & 2,778 & 75 \\
B3 & 125 & 134 & 1,567 & 54 \\
\hline
\end{tabular}

B1 - group administered adiCox ${ }^{\mathrm{SOL}} \mathrm{PF}$ in drinking water at a final dose of $1 \mathrm{~mL} / \mathrm{L}$ for three days prior to ORT vaccination

B2 - group administered adiCox ${ }^{\text {SOL }} \mathrm{PF}$ in drinking water at a final dose of $1 \mathrm{~mL} / \mathrm{L}$ for three days after ORT vaccination

B3 - control group

$\mathrm{CV}$ - coefficient of variation

The results of the selected cell-mediated immunity markers are presented in Table 3. They indicate that the therapeutic dose of the preparation $(3 \mathrm{~mL} / \mathrm{L}$ water) administered to birds in group A3 for three days caused a statistically significant increase in the percentage of $\mathrm{IgM}^{+} \mathrm{B}$ lymphocytes and a considerable (although statistically insignificant) increase in the percentage of $\mathrm{CD}^{+} \mathrm{T}$ lymphocytes in the spleen. The prophylactic dose of adiCox ${ }^{\text {SOL }} \mathrm{PF}$ ( $1 \mathrm{~mL} / \mathrm{L}$ water) brought about a statistically significant multiplication in the $\mathrm{CD} 4^{+} \mathrm{T}$ lymphocyte subpopulation in blood from Group A2 turkeys.

Experiment II. The results of serological analyses are provided in Table 4 . They show that both before (Group B1) and after (Group B2) vaccination, the turkeys receiving the prophylactic dose of the test preparation $(1 \mathrm{~mL} / \mathrm{L}$ water $)$ produced higher titres of anti-ORT antibodies than control birds (Group B3). However, the differences observed were statistically insignificant. A markedly higher titre of postvaccination antibodies was determined in birds receiving adiCox ${ }^{\text {SOLPF }}$ in drinking water for three days post vaccination.

\section{Discussion}

Turkey histomonosis, which was first described in 1983, has caused considerable losses in the turkey industry $(25,26)$. This situation prompted research aimed at developing effective preparations for the prevention and treatment of this dangerous disease. The widespread use of the preparations consequently developed minimised the problem of histomonosis in turkeys and other poultry species for many years (17). However, health problems in flocks of turkeys and chickens caused by $H$. meleagridis infection have reemerged in recent years since the imposition of a ban in the EU countries and the US on the use of histomonostats in poultry production based on international guidelines on food safety $(5,6,7)$.

The resurgence of turkey histomonosis was the stimulus for investigations to intensify again after a several-year break in research to develop effective preparations to combat this disease. It is now known that biosecurity measures alone are not effective enough (4) and that the main risk factors that predispose a domestic flock to histomonosis include the presence of wild birds within $1 \mathrm{~km}$ of the farm, water acidification, and failure on the part of workers and visitors to change shoes before entering the poultry house (9). This is also indicated by the results of a recently published study by Sulejmanovic et al. (30), who demonstrated the presence of $H$. meleagridis DNA in dust samples from a building housing clinically healthy turkeys.

The action strategy aimed at countering $H$. meleagridis infection in poultry flocks mainly entails searching for effective preparations of plant origin and developing a vaccine. As indicated by research findings (29), experimental vaccination using in vitro attenuated $H$. meleagridis effectively protects turkeys from histomonosis and is safe to use, which recommends it as the most promising means of prevention of histomonosis in poultry for the future. However, numerous publications show that, despite satisfactory in vitro results, phytocompounds fail to produce promising effects in vivo in the fight against this flagellate $(1,12,14,32)$. The likely reason for this failure is that in vivo, the $H$. meleagridis protozoan 
interacts with other pathogens and $E$. coli in particular $(10,16)$. This was not the case in our study, despite the isolation of $E$. coli from the internal organs of turkeys which died of histomonosis. This could be due to the immunomodulatory effect of the adiCox ${ }^{\text {SOLPF }}$ preparation, because our study results showed a tangible effect of its substances on the size of $\mathrm{T}$ and $\mathrm{B}$ lymphocyte subpopulations in both the blood and spleen of turkeys. The tested preparation also stimulated humoral immunity, which resulted in higher levels of anti-ORT antibodies in the groups of birds vaccinated against ornithobacteriosis and receiving adiCox ${ }^{\mathrm{SOL} P F}$. The results obtained correspond with those of previous studies, which demonstrated the immunomodulatory effect of phytoncides on humoral and cell-mediated immunity in chickens and turkeys (21). Our research also showed that, regardless of the dose used,

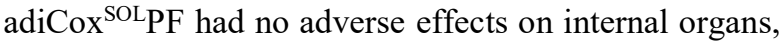
as confirmed by the results of biochemical analyses. The values of all biochemical parameters analysed in our study did not exceed the standard values of these parameters described by Krasnodębska-Depta and Koncicki (23).

The results of the present research confirm the high therapeutic and prophylactic effectiveness of the adiCox ${ }^{\text {SOLPF }}$ preparation used in a turkey breeder flock in which the clinical form of histomonosis was diagnosed during autopsy and confirmed by PCR. Over the entire 28-week rearing period, the mortality and culling rate was $28.3 \%$ in the flock of turkeys that underwent treatment and $4.53 \%$ in the flock of turkeys that did not get sick but received the prophylactic dose

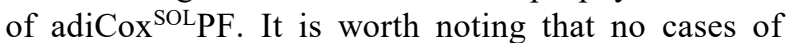
histomonosis were recorded among toms receiving the prophylactic dose even though they are considered more susceptible to infection by $H$. meleagridis than hens $(9,15)$. However, many publications show that histomonosis has recently been the cause of very high losses in flocks of broiler and breeder turkeys. The mortality rates in untreated turkey flocks ranged from $23 \%$ to over $83 \%$. With the use of preparations based on plant extracts or antibiotics (e.g. paromomycin), they were slightly lower but still ranged from 9 to $42 \%$ $(9,15,30)$. The birds were emaciated and very often culled before reaching slaughter age out of concern for their welfare. In addition to numerous deaths, laying declined or even completely ceased in affected breeding turkey flocks (9).

The very high effectiveness of the adiCox ${ }^{\text {SOLPF }}$ preparation tested is evidenced by the fact that no relapses occurred in the turkey breeder flock under therapeutic and prophylactic treatment due to histomonosis developed at 11 weeks of life. In week 28 , these turkeys were transferred to laying facilities and kept there until their $56^{\text {th }}$ week. Laying began in week 32. Production parameters (eggs/hen, fertility, and hatchability) as well as the mortality and culling rate determined over the 24-week production period did not deviate from the standard values for this type of turkey. An average of 112 eggs were obtained from a turkey hen from the facility where histomonosis was diagnosed in the rearing period. On the other hand, hens each produced five to seven eggs more as birds administered the prophylactic dose of adiCox ${ }^{\text {SOLPF }}$ during the rearing period, and no histomonosis was diagnosed in them even though they were kept in the turkey house adjacent to the one with the sick birds. Irrespective of the turkey house, the fertilisation and hatching rates were $97 \%$ and $85 \%$, respectively. Not a single case of histomonosis was detected in birds which were found dead or were euthanised, for which the respective rates ranged from $2.7 \%$ to $6.1 \%$ over the laying period.

The results of the present study allow it to be concluded that the active ingredients of the adiCox ${ }^{\text {SOLPF }}$ preparation are effective in the prevention and therapy of turkey histomonosis. The disease did not spread to turkey hens kept in an adjacent building and breeder turkeys were cured during the rearing period; these were both outcomes which demonstrated the efficacy of the preparation. That no disease recurred by the end of the rearing period nor within 24 weeks of laying production also confirms its high efficacy in eradicating turkey histomonosis as do the production results obtained (eggs/hen, fertility, and hatchability). It was also shown that, besides acting on pathogenic $H$. meleagridis flagellates, the plant extracts contained in the evaluated preparation stimulated both the humoral and cellmediated defence mechanisms of the birds without suppressing the functions of their internal organs. This was regardless of the dose being to prevent or to treat, as evidenced by the biochemical markers studied matching the physiological norms in value. Such therapeutic and prophylactic effects against histomonosis after the use of plant extracts have never been described before.

Conflict of Interests Statement: The authors declare that there is no conflict of interests regarding the publication of this article.

Financial Disclosure Statement: Part of this study was funded by Grelavi S.A. (Poland). The remaining part was financed from the statutory sources of the Faculty of Veterinary Medicine, University of Warmia and Mazury in Olsztyn (Poland). Publication was co-financed by the Minister of Science and Higher Education as part of the program entitled "Regional Initiative of Excellence" for the years 2019-2022, project no. 010/RID/2018/19.

Animal Rights Statement: Samples from turkeys were collected during clinical studies. Experimental and animal handling procedures were conducted with the approval of the Local Ethical Commission for Animal Experiments in Olsztyn (resolution no. $23 / 2016)$. 


\section{References}

1. Arshad N., Zitterl-Eglseer K., Hasnain S., Hess M.: Effect of Peganum harmala or its beta-carboline alkaloids on certain antibiotic resistant strains of bacteria and protozoa from poultry. Phytother Res 2008, 22, 1533-1538, doi: 10.1002/ptr.2528.

2. Baynes R.E., Dedonder K., Kissell L., Mzyk D., Marmulak T., Smith G., Tell L., Gehring R., Davis J., Riviere J.E.: Health concerns and management of select veterinary drug residues. Food Chem Toxicol 2016, 88, 112-122, doi: 10.1016/j.fct.2015.12.020.

3. Bobusia K.: Epizootic situation of histomonosis in broilers breeders flocks and turkeys flocks from selected areas of Poland and evaluation of diagnostic methods used to identify Histomonas meleagridis. PhD thesis, University of Life Sciences, Wrocław 2015.

4. Clark S., Kimminau E.: Critical review: Future control of blackhead disease (histomoniasis) in poultry. Avian Dis 2017, 61, 281-288, doi: 0.1637/11593-012517-ReviewR.

5. Codex Alimentarius Commission: Report of the twenty-second session of the Codex Committee on Residues of Veterinary Drugs in Foods. San Jose, Costa Rica, 2015.

6. Commission of the European Communities: Commission Regulation (EC) No 1798/95 of 25 July, 1995 amending Annex IV to Council Regulation (EEC) No 2377/90 laying down a Community procedure for the establishment of maximum residue limits of veterinary medicinal products in foodstuffs of animal origin. O J L 1995, 174, 38, 20-21.

7. Council of the European Union and European Parliament: Council Regulation (EC) No 1756/2002 of 23 September 2002 amending Directive 70/524/EEC concerning additives in feedingstuffs as regards withdrawal of the authorisation of an additive and amending Commission Regulation (EC) No 2430/1999. O J L 2002, 265, $45,1-2$.

8. Esquenet C., De Herdt P., De Bosschere H., Ronsmans S., Ducatelle R., Van Erum J.: An outbreak of histomoniasis in freerange layer hens. Avian Pathol 2003, 32, 305-308, doi: 10.1080/0307945031000097903.

9. European Food Safety Authority: Technical meeting on histomonosis in turkeys. EFSA supporting publication 2013:EN464. European Food Safety Authority, Parma, 2013.

10. Ganas P., Liebhart D., Glösmann M., Hess C., Hess M.: Escherichia coli strongly supports the growth of Histomonas meleagridis, in a monoxenic culture, without influence on its pathogenicity. Int J Parasitol 2012, 42, 893-901, doi: 10.1016/j.ijpara.2012.07.007.

11. Grabensteiner E., Hess M.: PCR for the identification and differentiation of Histomonas meleagridis, Tetratrichomonas gallinarum and Blastocystis spp. Vet Parasitol 2006, 142, 223-230, doi: 10.1016/j.vetpar.2006.07.011.

12. Grabensteiner E., Liebhart D., Arshad N., Hess M.: Antiprotozoal activities determined in vitro and in vivo of certain plant extracts against Histomonas meleagridis, Tetratrichomonas gallinarum and Blastocystis sp. Parasitol Res 2008, 103, 1257-1264, doi: 10.1007/s00436-008-1122-1.

13. Grabensteiner E., Liebhart D., Weissenböck H., Hess M.: Broad dissemination of Histomonas meleagridis determined by the detection of nucleic acid in different organs after experimental infection of turkeys and specified pathogen-free chickens using a mono-eukaryotic culture of the parasite. Parasitol Int 2006, 55, 317-322, doi.org/10.1016/j.parint.2006.07.004.

14. Hafez M.H., Houck R.: Efficacy of a herbal product against Histomonas meleagridis after experimental infection of turkey poults. Arch Anim Nutr 2006, 60, 436-442, doi: 10.1080/17450390600884500.

15. Hauck R., Stoute S., Chin R.P., Gabriel Sentíes-Cué C., Shivaprasad H.L.: Retrospective Study of Histomoniasis (Blackhead) in California Turkey Flocks, 2000-2014. Avian Dis 2018, 62, 94-100, doi: 10.1637/11772-112017-Reg.1.
16. Hess M.: Commensal or pathogen - a challenge to fulfil Koch's Postulates. Br Poult Sci 2017, 58, 1-12, doi: 10.1080/ 00071668.2016.1245849.

17. Hess M., Liebhart D., Bilic I., Ganas P.: Histomonas meleagridis - new insights into an old pathogen. Vet Parasitol 2015, 208, 67-76, doi: 10.1016/j.vetpar.2014.12.018.

18. Hu J., Fuller L., McDougald L.R.: Infection of turkeys with Histomonas meleagridis by the cloacal drop method. Avian Dis 2004, 48, 746-750, doi: 10.1637/7152.

19. Koncicki A., Bukowska A., Mazur-Gonkowska B., KrasnodębskaDepta A., Stenzel T.: Evaluating 4-nitrophenylarsonic acid efficacy in preventing Histomonas meleagridis invasions in turkeys (in Polish). Med Weter 2006, 62, 1191-1194.

20. Koncicki A., Krasnodębska-Depta A., Guiro S.: Hematological and biochemical studies in outbreak of histomoniasis in turkeys (in Polish). Med Weter 1999, 55, 674-676.

21. Koncicki A., Śmiałek M., Tykałowski B., Pestka D., Stenzel T.: The influence of phytoncides on the immune system of broiler chickens and turkeys. Cent Eur J Immunol 2015, 40, 287-291, doi: 10.5114/ceji.2015.54588.

22. Koncicki A., Tykałowski B., Stenzel T., Śmiałek M., Pestka D.: Effect of infection of turkeys with haemorrhagic enteritis adenovirus isolate on the selected parameters of cellular immunity and the course of colibacillosis. Pol J Vet Sci 2012, 15, 215-220, doi: 10.2478/v10181-011-0136-2.

23. Krasnodębska-Depta A., Koncicki A.: Diagnostyka Biochemiczna. In: Choroby drobiu Wydanie III, edited by M. Mazurkiewicz, A. Wieliczko, Wydawnictwo Uniwersytetu Przyrodniczego we Wrocławiu, Wrocław, 2019, pp. 895-909.

24. Kubińska M., Tykałowski B., Jankowski J., Koncicki A.: Immunological and biochemical indicators in turkeys fed diets with a different Methionine content. Pol J Vet Sci 2014, 17, 687-695, doi: 10.2478/pjvs-2014-0100.

25. Liebhart D., Ganas P., Sulejmanovic T., Hess M.: Histomonosis in poultry: previous and current strategies for prevention and therapy. Avian Pathol 2017, 46, 1-18, doi: 10.1080/03079457.2016.1229458.

26. McDougald L.R.: Blackhead disease (histomoniasis) in poultry: a critical review. Avian Dis 2005, 49, 462-476, doi: 10.1637/7420-081005R.1.

27. Patra G., Prasad H., Lalsiamthara J., Kataria J.L., Malsawmkima D., Lalrinkima H.: Prevalence of histomonas meleagridis in broiler chicken in different parts of Mizoram. India Int J Poult Sci 2013, 12, 98-101, doi: 10.3923/ijps.2013.98.101.

28. Popp C., Hauck R., Balczulat S., Hafez H.M.: Recurring histomonosis on an organic farm. Avian Dis 2011, 55, 328-330, doi: 10.1637/9596-110810-Case.1.

29. Sulejmanovic T., Bilic I., Hess M., Liebhart D.: An in vitro attenuated strain of Histomonas meleagridis provides crossprotective immunity in turkeys against heterologous virulent isolates. Avian Pathol 2016, 45, 46-53, doi: 10.1080/ 03079457.2015.1117057.

30. Sulejmanovic T., Turblin V., Bilic I., Jaskulska B., Hess M.: Detection of Histomonas meleagridis DNA in dust samples from apparent healthy meat turkey flocks without effect on performance. Avian Pathol 2019, 48, 329-333, doi: 10.1080/ 03079457.2019.1599819.

31. Thofner I.C., Liebhart D., Hess M., Schou T.W., Hess C., Ivarsen E., Frette X.C., Christensen L.P., Grevsen K., Engberg R.M., Christensen J.P Antihistomonal effects of artemisinin and Artemisia annua extracts in vitro could not be confirmed by in vivo experiments in turkeys and chickens. Avian Pathol 2012, 41, 487-496, doi: 10.1080/03079457.2012.714459.

32. Van der Heijden H.M., Landman W.J.: In vivo effect of herbal products against Histomonas meleagridis in turkeys. Avian Pathol 2008, 37, 45-50, doi: 10.1080/03079450701784883.

33. Van der Heijden H.M., Landman W.J.: High seroprevalence of Histomonas meleagridis in Dutch layer chickens. Avian Dis 2011, 55, 324-327, doi: 10.1637/9740-960911-DIGEST.1. 